<シンポジウム（2)-1-1>病態仮説に基づくアルツハイマー病治療法開発の現状と展望 コリン仮説に基づく $\mathrm{AD}$ 治療法開発の現状と展望

\author{
下濱俊1)
}

\begin{abstract}
要旨：1970 年代後半からの神経伝達物質の研究によりアセチルコリン（ACh）作動性神経系の障害がアルッ ハイマー病（AD）における認知症発現の主因であるとするコリン仮説が提唱された．その仮説に基づき AChの 分解を抑制しシナプス間隙の ACh 濃度を上昇させる目的で開発されたのが ACh 分解酵素阻害薬 (ChEl) である. ChEl としてドネペジルに加え 2011 年からガランタミンとリバスチグミンが AD 治療薬として本邦でも承認され た. ChEl には symptomatic effect だけでなく, 神経細胞保護や A 沈着抑制など AD の病態そのものに作用する disease modifier としての作用が明らかにされている.
\end{abstract}

(臨床神経 2013;53:1036-1038)

Key words : アルツハイマー病, コリンエステラーゼ阻害薬, ドネペジル, ガランタミン, リバスチグミン

\section{コリン仮説に基づく治療薬開発の経緯}

1970 年代後半に神経伝達物質の研究が盛んにおこなわれ るようになり, $\mathrm{AD}$ 脳大脳皮質で正常対照群と比較してアセ チルコリン $(\mathrm{ACh})$ 合成酵素のコリンアセチルトランスフェ ラーゼ (choline acetyltransferase; ChAT) 活性や ACh 分解酵 素のアセチルコリンエステラーゼ（AChE）活性が低下して いることが発見され，さらに， $\mathrm{AD}$ 患者の大脳皮質 $\mathrm{ChAT}$ 活 性と認知機能スコアが相関していることが報告された ${ }^{122)}$. また，前脳基底部に神経細胞群を有し，大脳新皮質や海馬に 投射する ACh 作動性神経経路が知られているが， $\mathrm{AD}$ 脳前脳 基底部で $\mathrm{ACh}$ 作動性神経細胞の顕著な脱落がみとめられる ことが報告された ${ }^{3)}$. AChはムスカリン性 $\mathrm{ACh}$ 受容体 (mAChR) とニコチン性 ACh 受容体 (nAChR) に結合するが, $\mathrm{AD}$ に扔いて顕著な $\mathrm{nAChR}$ 数の減少も報告された ${ }^{4)}$. 動物実 験からニコチンの刺激によってシナプス前神経終末の $\mathrm{nAChR}$ を活性化されると ACh, グルタミン酸, ノルアドレ ナリン，ドパミンなどの神経伝達物質の放出が促進されるこ とが示されている ${ }^{5}$.

薬理学的研究で AChE 阻害薬やニコチンにより脳内 ACh 系神経伝達が促進され，アトロピンやスコポラミンによる脳 内 $\mathrm{ACh}$ 系神経伝達の遮断により学習や記憶行動が抑制され ることが示された。これらのことから，ACh 作動性神経系 の障害が $\mathrm{AD}$ の主要な病態の一つとするコリン仮説が提唱さ れた ${ }^{5)}$.

$\mathrm{AChE}$ 阻害薬は, ACh の分解を抑制しシナプス間隙の $\mathrm{ACh}$ 濃度を上昇させる作用があり,これにより $\mathrm{ACh}$ 神経系の伝達 を促進し記憶障害などの $\mathrm{AD}$ の認知症症状を改善すると考え られている，現在，世界的に広く臨床応用されている $\mathrm{AChE}$
阻害薬はドネペジル, ガランタミン, リバスチグミンである。 本邦では 10 年以上ドネペジルしか使用できなかったが, 2011 年よりガランタミンおよびリバスチグミンも使用可能 となった ${ }^{6)}$.

\section{各 ChE 阻害薬の薬理作用の違い}

ドネペジルは，わが国で最初に $\mathrm{AD} に$ に対する抗認知症薬と して認可された AChE 阻害薬である。中枢神経への移行が高 く，末梢組織での AChE 阻害作用による副作用の少ないのが 特徴である.

リバスチグミンは $\mathrm{ACh}$ 分解酵素である $\mathrm{AChE}$ とブチリル コリンエステラーゼ $(\mathrm{BuChE})$ の両者を阻害する作用を持っ ている. $\mathrm{AD} の$ 進行にともない神経細胞の脱落が抗こり $\mathrm{AChE}$ 活性は低下するが, グリアにも発現する BuChE 活性 は増加して抢り、リバスチグミンの BuChE 阻害作用により シナプス間隙の $\mathrm{ACh}$ 濃度が一層増加することが推測される. パッチ剂は経口剂にみられるような血中濃度の急激な上昇が なく, 消化器症状の認容性やコンプライアンスの向上が期待 できる。

ガランタミンは, AChE 阻害作用に加えて nAChR 受容体 のアロステリックモジュレーター（APL）として作用し， $\mathrm{nAChR}$ の機能を充進させることが推定される。シナプス前 の nAChRに作用することにより ACh のみならず種々の神経 伝達物質の遊離を促進することにより認知機能障害や行動異 常・精神症状への効果が期待される.

このように, 各 $\mathrm{ChE}$ 阻害薬は $\mathrm{AChE}$ 阻害作用という共通 点はあるがその阻害様式や強度に違いがあり，また， BuChE 阻害作用や nAChRへのアロステリック作用に違いがある.

1) 札幌医科大学医学部神経内科学講座〔 $\bar{\top} 060-8543$ 北海道札幌市中央区南一条西 16 丁目 291〕

(受付日：2013 年 5 月 30 日) 
$\mathrm{AD}$ 治療のアルゴリズムである $\mathrm{ChE}$ 阻害剤で効果が不十分な ばあいには他の ChE 阻害剤に変更する根拠の一つである ${ }^{5 / 6)}$.

\section{ChE 阻害薬の病態修飾作用}

\section{神経保護作用}

ニコチンおよび $\mathrm{ChE}$ 阻害薬がグルタミン酸誘発神経毒性 が（ネクローシス）に対して保護効果を示し，その分子機序 として nAChR を介した一酸化窒素（NO）産生酵素活性の抑 制作用が考えられ，また， $\mathrm{A} \beta$ 打よび $\mathrm{A} \beta$ 増強グルタミン酸 誘発神経細胞死（アポトーシス）に対しても保護作用を示し， その作用機序として $\alpha 7 \mathrm{nAChR}-\mathrm{PI} 3 \mathrm{~K}-\mathrm{Akt}$ 系の活性化によるア ポトーシス抑制タンパク質である Bcl-2 の増加が抏こること が示されている78)

\section{$\mathrm{A} \beta$ 産生抑制作用}

初代培養ラット大脳皮質神経細胞にニコチンおよび $\mathrm{ChE}$ 阻害薬を処置すると，アミロイド前駆タンパク質（ $\beta$-amyloid precursor protein; APP）の $\alpha$ 切断が活性化し，培養上清中の $\mathrm{APP} \alpha$ が増加し，A 濃度が減少することが示された。

$\mathrm{nAChR}$ を介するミクログリアの AA 荟食促進作用

$\mathrm{AD}$ 脳の老人斑のミクログリアには $\alpha 7 \mathrm{nAChR}$ が発現して いる，初代培養ミクログリアは $\mathrm{A} \beta$ を頜食するが，その貪食 作用はニコチンにより促進された。nAChRの APL 作用を有 するガランタミンは, 初代培養ミクログリアの $\mathrm{A} \beta$ 貪食能を 促進した。ささらに, 脳内に $\mathrm{A} \beta$ が蓄積するよう遺伝子操作さ れたマウスに対しガランタミンを長期間投与すると $\mathrm{A} \beta$ 沈着 が減少し, 認知・記憶機能が改善した。ミクログリアに発現 する $\mathrm{nAChR}$ が新たな $\mathrm{AD}$ 治療薬の標的となりえる可能性が ある ${ }^{9)}$.

成体ラット海馬神経新生に拄けるコリン作動性神経系の関与 ドネペジルによる $\mathrm{mAChR}$ の活性化が CREB リン酸化のシ グナル伝達経路を介して新生細胞の生存にかかわっているこ と, 一方, 神経幹・前駆細胞の増殖, 神経細胞への分化には 関与しないことが報告されている ${ }^{10)}$.

\section{コリン仮説に基づく $A D$ 治療法開発の今後の課題と展望}

今後, 中枢への移行が良く末梢での副作用の少ない新たな $\mathrm{ChE}$ 阻害薬や $\mathrm{nAChR}$ 作動薬の開発や前脳基底部のコリン 作動性神経細胞の神経変性を抑制する方法の開発が期待さ れる。これらの薬剤は症状改善をもたらす symptomatic treatment としての作用だけでなく, 病態そのものに作用し て病気の進行抑制, 病態の改善をもたらす disease modifier と しての作用の可能性を示寸研究結果が報告されており, アミ ロイドカスケードに作用する新規の $\mathrm{AD}$ に対する治療薬が登 場した後も $\mathrm{ChE}$ 阻害薬は長く利用され続けるものと考えら れる。

※本論文に関連し，開示すべきCOI 状態にある企業，組織，団体 講演料：武田薬品株式会社会社, 第一三共株式会社, ノバルティス ファーマ株式会社, ヤンセンファーマ株式会社

\section{文 献}

1) Davies P, Maloney AJ. Selective loss of central cholinergic neurons in Alzheimer's disease. Lancet 1976;2:1403.

2) Bowen DM, Smith CB, White P, et al. Neurotransmitter-related enzymes and indices of hypoxia in senile dementia and other abiotrophies. Brain 1976;99:459-496.

3) Whitehouse PJ, Price DL, Clark AW, et al. Alzheimer disease: evidence for selective loss of cholinergic neurons in the nucleus basalis. Ann Neurol 1981;10:122-126.

4) Shimohama S, Taniguchi T, Fujiwara M, et al. Changes in nicotinic and muscarinic cholinergic receptors in Alzheimer-type dementia. J Neurochem 1986;46:288-293.

5）下濱 俊。アルッハイマー病の治療一現状と解決すべき諸 問題. 日本薬理会誌 2008;131:351-356.

6）下濱 俊．認知症治療薬の新たな展開．Annual Review 2012 神経。中外医学社；2012.pp. 75-84

7) Kihara T, Shimohama S, Sawada H, et al. Nicotinic receptor stimulation protects neurons against beta-amyloid toxicity. Ann Neurol 1997;42:159-163.

8) Kihara T, Shimohama S, Sawada H, et al. alpha 7 nicotinic receptor transduces signals to phosphatidylinositol 3-kinase to block a beta-amyloid-induced neurotoxicity. J Biol Chem 2001; 276:13541-13546.

9) Takata K, Kitamura Y, Saeki M, et al. Galantamine-induced amyloid- $\beta$ clearance mediated via stimulation of microglial nicotinic acetylcholine receptors. J Biol Chem 2010;285:4018040191.

10) Kotani $S$, Yamauchi T, Teramoto $T$, et al. Pharmacological evidence of cholinergic involvement in adult hippocampal neurogenesis in rats. Neuroscience 2006;142: 505-514. 


\title{
Abstract \\ The development of therapies for Alzheimer's disease based on cholinergic hypothesis-status quo and future directions
}

\author{
Shun Shimohama, M.D., Ph.D. ${ }^{1)}$ \\ ${ }^{1)}$ Neurology, Sapporo Medical University School of Medicine
}

Numerous approaches have been explored to treat individuals with Alzheimer's disease (AD). General approaches include the following treatment; treatment of cognitive symptoms, slowing decline, delaying onset of disease, and primary prevention. 2011 is the new era for the drug therapy for AD in Japan, because three anti-dementia drugs, galantamine, rivastigmine and memantine, were admitted to use for $\mathrm{AD}$ in addition to donepezil. Donepezil, galantamine and rivastigmine has been developed based on cholinergic hypothesis that acetylcholine (ACh) acts a chief neurotransmitter as a cognitive neurotransmitter. Donepezil a specific acetylcholinesterase inhibitor (AChEI). Galantamine acts as an allosteric potentiating ligand of nicotinic acetylcholine receptors in addition to the function of AChEI. Rivastigmine increase acetylcholine in the cholinergic synapse by inhibition of both AChE and butyrylcholinesterase. Recent study shows that these anti-dementia drugs afford symptomatic effect and also act as disease-modifiers which inhibit neuronal death and abnormal amyloid-beta deposition. These effects can slow the rate of decline of the disease. While in the past many of our attempts have been to treat secondary symptoms or improve the cognitive deficits, future attempts are likely to focus on slowing the rate of decline, delaying the onset of appearance, or preventing the disease.

(Clin Neurol 2013;53:1036-1038)

Key words: Alzheimer's disease, cholinesterase inhibitor, donepezil, galantamine, rivastigmine 